\title{
MANFAAT ANALISIS YURIDIS DAN SOSIOLOGIS YANG BERSIFAT KOMPLEMENTER DALAM PERJANJIAN KREDIT UNTUK MEMINIMALISIR RESIKO BANK SEBAGAI KREDITOR
}

\author{
Misahardi Wilamarta dan Zulfadli Barus \\ Fakultas Hukum Universitas Bhayangkara Jakarta* \\ dan Dosen Tetap Fakultas Hukum UPN "Veteran" Jakarta** \\ e-mail: misa@cbn.net.id dan e-mail: zfdlibrs@yahoo.com
}

\begin{abstract}
As a financial institution, bank has collected money from society and landing credit to debtors who need it to support their own businesses. As a kind trust business, bank have delivered credit to debtors which are based on the prudence principle, in order to make a bank in secured position for taking profit. Therefore, bank has used complementary approach like juridical and sociological approaches. Through this approaches, a bank could get safety position in legal and financial aspects. That's why, by landing credit a bank could get profit and risk minimized.
\end{abstract}

Key words : Bank, trust of business, credit, risk.

\begin{abstract}
Abstrak
Bank sebagai lembaga keuangan berfungsi menghimpun dana dari masyarakat dan menyalurkannya dalam bentuk kredit untuk pengembangan usaha bagi mereka yang memerlukannya berdasarkan prinsip kehati-hatian, agar tidak merugikan bank dan nasabah penabung, sehingga bisnis perbankan disebut sebagai bisnis kepercayaan. Agar supaya proses penyaluran kredit aman secara hukum dan menguntungkan secara ekonomis, maka bank melakukan pendekatan yuridis dan sosiologis secara komplementer. Dengan cara ini, bank dapat meminimalisir resiko dan sekaligus memperoleh keuntungan.
\end{abstract}

Kata kunci : Bank, bisnis kepercayaan, kredit, resiko. 


\section{A. Pendahuluan}

Bank adalah suatu lembaga keuangan yang eksistensinya tergantung mutlak pada kepercayaan nasabahnya yang mempercayakan dana dan jasa-jasa lain yang dilakukan mereka melalui bank pada khususnya dan dari masyarakat luas pada umumnya. Oleh karena itu, bank sangat berkepentingan agar kadar kepercayaan masyarakat, baik yang sudah maupun yang akan menyimpan dananya serta yang telah atau akan menggunakan jasa-jasa bank lainnya terpelihara dengan baik dalam tingkat yang tinggi. Mengingat bank adalah bagian dari sistem keuangan dan sistem pembayaran tentu masyarakat luas berkepentingan atas kesehatan dari sistem-sistem tersebut (Adrian Sutedi, 2007: 1).

Sebagai lembaga keuangan, bank memegang peran penting sebagai perantara dalam menghimpun dana dan mendistribusikan dari dan untuk masyarakat, baik dalam bentuk tabungan maupun pemberian kredit. Sebagai lembaga perantara antara penabung dan peminjam, bank dapat berfungsi ganda, yaitu sebagai debitor dan juga kreditor.

Bank berstatus debitor bila berhadapan dengan penabung, karena bank harus memenuhi prestasinya dalam bentuk pembayaran bunga (bank konvensional) dan bagi hasil (bank syariah) dalam waktu yang telah disepakati. Sebaliknya bank dapat berstatus sebagai kreditor dan berhak menerima prestasi dalam bentuk pembayaran cicilan hutang baik terhadap pokok dan bunganya dari peminjam (debitor) sebagai akibat dari suatu perjanjian pembiayaan.

Fenomena ini menunjukkan bahwa profit dalam bisnis jasa perbankan ini didasarkan pada selisih antara persentase kewajiban bank terhadap penabung dengan hak bank dari peminjam kredit. Bank akan untung bila persentase bunga atau bagi hasil kredit pembiayaan lebih besar dari persentase kewajiban bank terhadap penabung.

Dengan demikian jelas terlihat bahwa kunci keberhasilan bisnis ini adalah pada "kepercayaan", baik kepercayaan masyarakat untuk menyimpan uangnya di bank dan atau kepercayaan masyarakat untuk meminjam uang ke bank. Peningkatan saving yang tidak diimbangi dengan landing berakibat pada menumpuknya dana di bank (over likuiditas), sedangkan meningkatnya angka permintaan pembiayaan yang tidak diimbangi peningkatan saving, menyebabkan bank kekurangan dana.

Berkaitan dengan hal tersebut, tulisan ini bermaksud menganalisis kredit macet sebagai salah satu aspek yang dapat membahayakan eksistensi bank karena kredit macet dapat mengakibatkan bank tidak mendapatkan bunga atau bagi hasil dari debitor, yang diperlukan untuk memenuhi kewajibannya pada pihak penabung dan untuk operational cost bank itu sendiri.

Oleh karena itu, fokus tulisan ini adalah analisis yuridis dan sosiologis guna menghindari bank mengalami kerugian. Itulah sebabnya tulisan ini diberi judul "Manfaat Analisis Yuridis Dan Sosiologis Yang Bersifat Komplementer Dalam Perjanjian Kredit Untuk Meminimalisir Resiko Bank Sebagai Kreditor".

Seorang account manager bank pasti telah mengetahui dan memahami prinsip-prinsip dasar pemberian kredit kepada nasabah secara sosiologis, melalui analisa finansial. Namun pengetahuan tersebut belumlah cukup karena masih diperlukan analisis tambahan yang bersifat yuridis terhadap setiap perjanjian yang menjadi dasar pemberian kredit. Ibarat manusia, analisis yuridis merupakan "ruh" karena menyangkut hubungan hukum antara pemberi dan penerima pembiayaan, sedangkan analisis sosiologis merupakan fisiknya. Manusia tanpa ruh disebut mayat dan ruh tanpa ada fisik bukanlah manusia. Jadi, analisis sosiologis dan analisis yuridis bersifat komplementer (saling melengkapi) untuk membantu bank menghindari resiko, antara lain adalah munculnya kredit macet. 


\section{B. Kerangka Pemikiran}

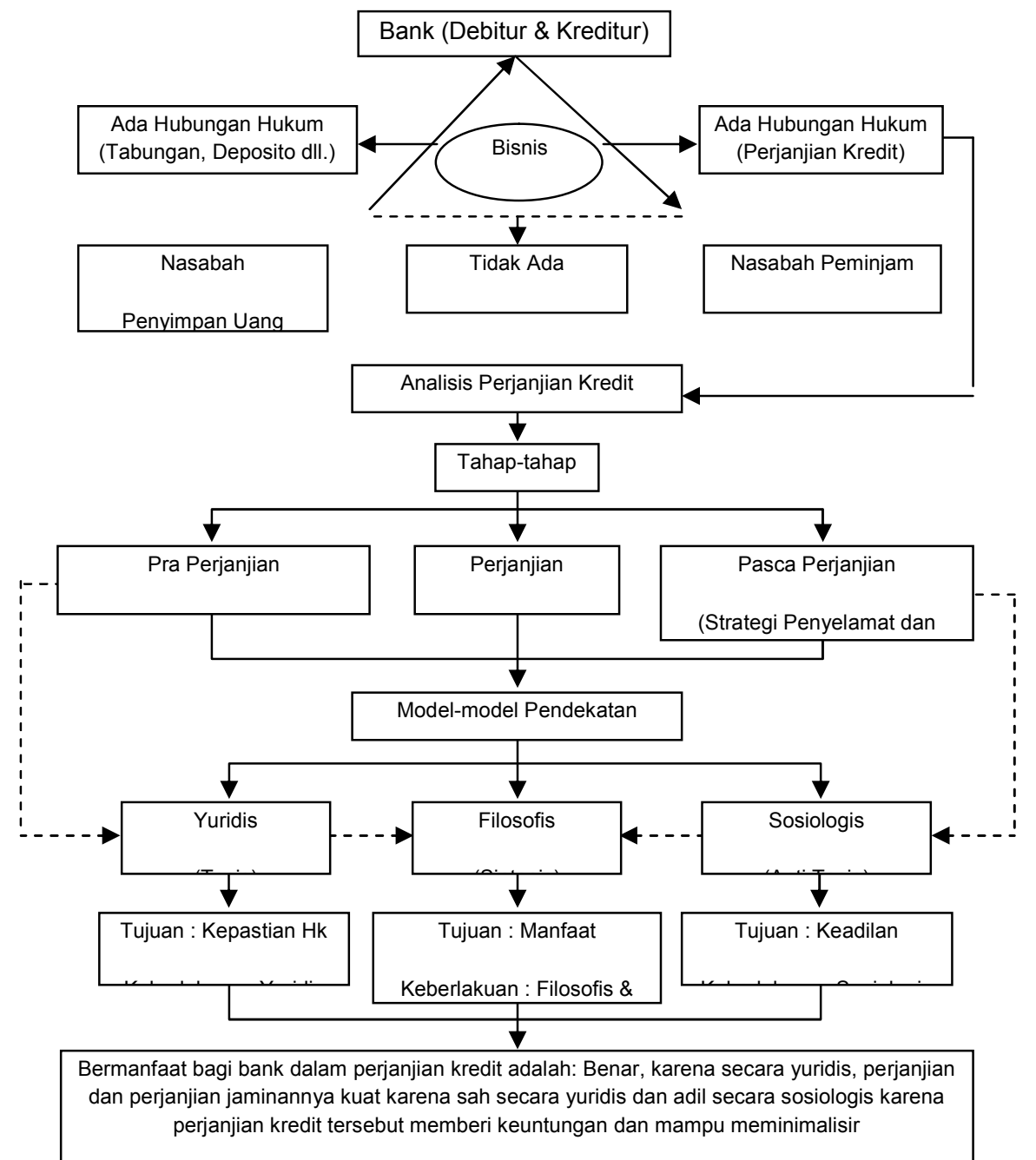

Skema diatas menunjukkan bahwa analisis yang digunakan oleh bank dalam perjanjian kredit adalah penggabungan antara pendekatan yuridis dan sosiologis agar bank memperoleh manfaat karena dapat terhindar dari resiko antara lain munculnya kredit macet, karena kedua pendekatan tersebut bersifat komplementer (saling melengkapi). Pendekatan yuridis dapat menjamin bahwa perjanjian kredit dan perjanjian jaminannya sah secara hukum sehingga kedudukan bank sebagai kreditor menjadi kuat, sedangkan pendekatan sosiologis (analisis financial) ingin mengetahui kemampuan bayar debitor dan andaikan dalam perjalanannya debitor tidak dapat melaksanakan kewajiban seperti yang diperjanjikan, maka untuk mengantisipasi resiko, bank dapat melakukan pendekatan strategi penyelamatan kredit (pendekatan sosiologis) dan strategi penyelesaian kredit (pendekatan yuridis).

Dalam kaitan ini terlihat ada dialektika antara pendekatan yuridis (tesis), pendekatan sosiologis (anti tesis) dan pendekatan filosofis (sintesis), seperti yang dikemukakan Hegel (Harry Hamersma, 1984: 40). Dalam pandangan penulis, karena pendekatan yuridis berorientasi pada kepastian hukum yang meletakkan kaidah hukum (ketentuan-ketentuan perjanjian, perjanjian kredit dan perjanjian jaminan) lebih dominan dari kepentingan para pihak

Manfaat Analisis Yuridis Dan... 
(kreditor dan debitor), sedangkan pada pendekatan sosiologis (kepentingankepentingan para pihak) lebih dominan dari kaidah-kaidah hukum sehingga dimungkinkan perubahan kaidah-kaidah hukum (pasal-pasal perjanjian kredit) yang telah disepakati sebelumnya melalui mekanisme addendum dan dilakukannya strategi penyelamatan kredit berupa rescheduling, reconditioning dan restructuring (Misahardi Wilamarta, 2006: 45).

Bila pendekatan yuridis lebih menekankan pada wujudnya kepastian hukum (tesis) dan pendekatan yuridis mengakomodir aspek keadilan (anti tesis), maka pendekatan filosofis berorientasi pada tegaknya nilai-nilai kepastian dan keadilan secara seimbang pada saat sebelum akad kredit, pada saat akad kredit dan pasca akad kredit. Itu sebabnya pendekatan filosofis berorientasi pada manfaat bagi kedua belah pihak terutama bagi kepentingan bank selaku kreditor.

\section{Pendekatan Hukum}

Bila kita membicarakan tentang hukum, pada umumnya pandangan para ahli hukum dapat dikelompokkan dalam 3 (tiga) model pendekatan: Normatif, sosiologis dan filosofis (Zulfadli Barus, 2009: 59-60).

Dikatakan normatif, karena hukum itu diasumsikan sebagai sesuatu yang otonom sehingga keberlakuannya ditentukan oleh hukum itu sendiri bukan oleh faktorfaktor di luar hukum. Karenanya, hukum itu telah dianggap sempurna dan final sehingga tinggal dilaksanakan. Mengapa demikian? Karena hukum itu adalah perintah dari yang berdaulat, maka apabila tidak dilaksanakan akan mendapatkan sanksi. Jadi suka atau tidak suka, terpaksa atau tidak, tingkah-laku setiap orang dalam masyarakat harus mengikuti kemauan hukum, sebab hukumlah yang berdaulat (Zulfadli Barus, 2004: 81).

Dengan pandangan ini tujuan hukum yang ingin diwujudkan adalah kepastian hukum dan karenanya keberlakuannya disebut dengan keberlakuan yuridis. Dalam konteks ini hukum bertindak

Yustisia Vol.1 No.2 Mei - Agustus 2012 sebagai "tuan" dan masyarakat adalah "pelayannya". Terkait dengan hubungan hukum perjanjian kredit antara bank dengan debitor, maka semua kepentingan para pihak harus tunduk pada aturan hukum yang berlaku.

Dalam pendekatan sosiologis, hukum itu diasumsikan sebagai sesuatu yang tidak otonom sehingga keberlakuannya ditentukan oleh faktor-faktor non yuridis, karena hukum sebagai gejala sosiologis adalah produk interaksi sosial (ekonomi, politik dan lain-lain). Dengan pandangan ini, tujuan hukum yang ingin diwujudkan adalah keadilan hukum. Artinya, hukum dipatuhi oleh masyarakat sehingga efektif berlaku karena hukum tersebut dianggap telah merupakan representasi dari rasa keadilan yang tumbuh dan berkembang di masyarakat. Akibatnya, hukum harus berubah mengikuti perubahan masyarakat. Jadi, posisi hukum itu adalah "pelayan" dan masyarakat (interaksi sosial) adalah "tuannya". Terkait dengan hubungan hukum perjanjian kredit, meski bank dan debitor telah bersepakat terhadap isi perjanjian, tetapi dalam perkembangannya masih terbuka peluang untuk dilakukan perubahan terhadap isi perjanjian bila debitor mengalami kesulitan melaksanakan kewajibannya melalui mekanisme addendum yang disepakati bersama, sebagai wujud akomodasi dari rasa keadilan.

Dalam pendekatan filosofis, hukum itu otonom atau tidak otonom bukanlah merupakan isu sentral, karena yang penting adalah apakah hukum itu bermanfaat mewujudkan nilai-nilai keadilan dan kebenaran, terlepas apakah ia merupakan output dari proses sosiologis empiris atau output dari proses yuridis rasional. Bila hukum tidak merupakan cerminan nilai-nilai keadilan dan kebenaran, maka hukum tersebut tidak memiliki legitimasi filosofis. Artinya, hukum yang seperti itu tidak wajib dipatuhi karena ia telah kehilangan dasar mengikat. Dengan pandangan ini, tujuan yang ingin dicapai adalah kemanfaatan dalam arti keseimbangan antara kebenaran (kepastian hukum) yang bersifat yuridis rasional dengan keadilan (keadilan hukum) yang bersifat sosiologis empiris. Ini seperti timbangan yang merupakan simbol hukum.

Manfaat Analisis Yuridis Dan...

154 
Timbangan itu menunjukkan pada besar kecilnya manfaat hukum. Artinya, manfaat hukum semakin besar manakala timbangan itu menunjukkan keseimbangan antara hak (keadilan) dan kewajiban (kebenaran), demikian pula sebaliknya, manfaat hukum akan semakin berkurang bila tidak seimbang.

Terkait dengan tulisan ini, penulis ingin menunjukkan bahwa manfaat akan diperoleh bank sebagai kreditor dalam proses pembiayaan manakala analisis yuridis dan normatif digunakan secara bersamaan, baik pada tahap pra pembiayaan, pembiayaan dan pasca pembiayaan. Kedua analis tersebut bersifat komplementer (saling melengkapi) guna memberi manfaat bagi bank sebagai kreditor agar terhindar dari kerugian.

\section{Pengertian Kredit}

Kata kredit berasal dari kata Romawi "Credere" yang berarti kepercayaan, atau "Credo" yang berarti saya dipercaya. Dalam bahasa Inggris "Believe atau Trust" artinya sama yaitu percaya. Kepercayaan adalah unsur yang sangat penting dan utama dalam pergaulan hidup manusia karena tanpa itu, kerjasama sulit terlaksana. Tanpa kerjasama banyak harapan dalam kehidupan bersama tidak dapat diwujudkan, termasuk dalam hal pembiayaan (kredit). Orang yang mendapat pinjaman uang dari bank adalah orang yang dipercaya akan mampu dan mau mengembalikan pinjaman tepat pada waktunya disertai imbalan bunga serta menggunakan pinjaman sesuai tujuan.

Menurut Molenaar :

"Kredit adalah meminjamkan benda pada peminjam dengan kepercayaan, bahwa benda itu akan dikembalikan dikemudian ahri kepada pihak yang meminjamkan" (Mariam Darus, 2001 : 138).

Menurut UU No.10 tahun 1998 tentang Perbankan, Pasal 1 point 11 menyatakan :

Yustisia Vol.1 No.2 Mei - Agustus 2012
"Kredit adalah penyediaan uang atau tagihan yang dapat dipersamakan dengan itu, berdasarkan persetujuan atau kesepakatan pinjam meminjam antara bank dengan pihak lain yang mewajibkan pihak peminjam untuk melunasi hutangnya setelah jangka waktu tertentu dengan pemberian bunga."

Menurut UU No.10 tahun 1998 tentang Perbankan, Pasal 1 point 12 menyatakan :

"Pembiayaan berdasarkan Prinsip Syariah adalah penyediaan uang atau tagihan yang dipersamakan dengan itu berdasarkan persetujuan atau kesepakatan antara bank dengan pihak lain yang mewajibkan pihak yang dibiayai untuk mengembalikan uang atau tagihan tersebut setelah jangka waktu tertentu dengan imbalan atau bagi hasil."

\section{E. Kredit dan Pengembangan Usaha}

Salah satu sumber dana bagi bank adalah dengan menyalurkan kredit kepada masyarakat, baik perorangan maupun badan usaha untuk memenuhi kebutuhan yang bersifat konsumtif atau kebutuhan produktif. Itulah sebabnya, setiap orang atau badan usaha yang ingin meningkatkan kebutuhan konsumtif atau produktifnya tetapi tidak memiliki modal yang cukup, sangat memerlukan pendanaan dari bank, antara lain dengan cara meminjam kredit.

Sebenarnya, dana yang disalurkan oleh bank kepada masyarakat dalam bentuk kredit tersebut bukanlah dana milik bank sendiri tetapi dana yang berasal dari masyarakat yang menyimpan uangnya di bank tersebut. Sehingga penyaluran kredit harus dilakukan dengan prinsip kehati-hatian (prudence) sebagai salah satu prinsip dasar dalam etika bisnis (Misahardi Wilamarta, 2007: 49), melalui analisa yuridis dan sosiologis yang digunakan pada saat pengajuan proposal kredit, persetujuan kredit dan pasca akad kredit. Karena, perjanjian kredit yang sah dan pengikatan

Manfaat Analisis Yuridis Dan... 155 
jaminan yang kuat (faktor yuridis) dan dokumentasi perkreditan yang teratur dan lengkap tentang penyaluran, pengawasan dan pemantauan (faktor sosiologis) merupakan faktor-faktor penentu agar kredit yang disalurkan tersebut dapat kembali tepat pada waktunya.

Kredit yang dikelola dengan prinsip kehati-hatian akan menempatkan kredit yang disalurkan bank pada kualitas kredit yang Performing Loan sehingga dapat memberikan pendapatan yang besar bagi bank, yaitu selisih antara pendapatan bunga atau bagi hasil yang dibayar para pemohon kredit dengan pengeluaran bunga (konvensional) atau bagi hasil (syariah) untuk penabung serta pengeluaran untuk biaya operasional bank. Agar pengelolaan kredit menjadi sehat dan menguntungkan maka sejak awal proses permohonan kredit harus dilakukan analisa yang akurat dan mendalam terhadap calon debitur, baik aspek sosiologis (kemampuan bayarnya/finansial) dan aspek yuridis (keabsahan jaminannya) agar dapat mengantisipasi kemungkinan munculnya kredit macet yang dapat merugikan bank.

Aspek yuridis adalah aspek yang sangat penting dalam pemberian kredit sehingga sebaiknya pejabat pengelola kredit harus memiliki pengetahuan hukum agar terhindar dari kemungkinan munculnya akibat hukum berupa batal demi hukum atau dapat dibatalkan.

Aspek sosiologis (analisis finansial) menjadi penting dalam pemberian kredit karena untuk mengetahui kemampuan bayar dari debitor. Tanpa kemampuan bayar yang dimiliki oleh calon debitor, peluang munculnya kredit macet adalah besar. Selain itu, aspek sosiologis diperlukan pula ketika muncul fakta-fakta empiris pasca akad kredit yang memerlukan perubahan pasal-pasal dalam perjanjian yang sebelumnya telah disepakati, dalam bentuk addendum.

\section{F. Perjanjian dan Perjanjian Kredit}

Perjanjian adalah suatu hubungan hukum antara 2 (dua) pihak berdasarkan mana pihak yang satu berhak menuntut suatu hal dari pihak lain yang berkewajiban

Yustisia Vol.1 No.2 Mei - Agustus 2012 memenuhi tuntutan itu (R. Subekti, 1963 : 4). Sedangkan perjanjian kredit adalah perjanjian pinjam meminjam antara bank dan pihak peminjam dalam mana bank berhak memberikan kredit kepada peminjam dan peminjam berkewajiban melunasi kredit tersebut dalam jangka waktu yang ditentukan dengan jumlah bunga, imbalan atau pembagian hasil keuntungan yang telah ditetapkan (Abdulkadir Muhammad, 1995 : 206)

Perjanjian sebagai hubungan antar para pihak dapat mengakibatkan 3 (tiga) kemungkinan : sah, batal demi hukum dan dapat dibatalkan.

Suatu perjanjian dikatakan sah, bila syarat-syarat subyektif (para pihak sebagai subyek hukum) dan syarat-syarat obyektif (benda yang diperjanjikan) terpenuhi. Bila syarat subyektifnya tidak terpenuhi perjanjian itu dapat dibatalkan dan bila syarat obyektifnya tidak terpenuhi maka perjanjian tersebut dikatakan sebagai batal demi hukum (Djumadi, 1995 : 16).

Bila akibat hukum dari suatu perjanjian itu adalah sah dan atau batal demi hukum, jelas-jelas telah memberi kepastian hukum. Perjanjian yang sah tidak menimbulkan masalah karena para pihak tinggal melaksanakan prestasi seperti yang telah mereka sepakati. Dikatakan perjanjian itu batal demi hukum berarti para pihak tidak boleh melakukan prestasi seperti yang telah diperjanjikan karena isi perjanjian ternyata bertentangan dengan kesusilaan, ketertiban umum dan peraturan perundangundangan yang berlaku (Zulfadli Barus, $2004: 2$ ).

Sedangkan perjanjian yang berakibat dapat dibatalkan mengandung 2 (dua) kemungkinan, yaitu para pihak dapat tidak melaksanakan prestasi dan dapat pula melaksanakannya. Hal ini tergantung pada ada tidaknya keberatan dari pihak ketiga yang merasa dirugikan dengan adanya perjanjian tersebut. Bila tidak ada complain dari pihak yang dirugikan, maka perjanjian tersebut akan berjalan terus (sah) dan bila ada complain, maka perjanjian itu dapat dibatalkan berdasarkan putusan hakim.

Bila kita menganalogikan ketiga macam akibat hukum ini dengan warna, maka warna putih (sah), warna hitam (batal demi hukum) dan warna abu-abu (dapat

Manfaat Analisis Yuridis Dan...

156 
dibatalkan). Berhubung dapat dibatalkan ada di grey area maka ini dapat berubah menjadi putih (sah) dan atau berubah menjadi hitam (batal demi hukum).

Oleh karena itu, agar perjanjian kredit tidak mengarah pada munculnya kredit macet, maka setiap perjanjian kredit haruslah dirancang sedemikian rupa oleh bank agar menjadi sah dan bukan pada posisi dapat dibatalkan dan atau batal demi hukum.

Perjanjian kredit itu dikatakan sah karena mensyaratkan unsur-unsur yang harus ada dalam suatu perjanjian yaitu : subyek hukumnya minimal dua orang atau lebih, ada hubungan hukum diantara mereka dan adanya prestasi (obyek perjanjian). Dengan kata lain suatu perjanjian kredit dianggap sah dan memenuhi syarat apabila memenuhi syarat-syarat subyektif (kesepakatan para pihak berdasarkan asas kebebasan berkontrak dan kecakapan untuk membuat suatu perikatan). Sedangkan unsur-unsur obyektifnya adalah obyek perjanjian berupa barang yang halal karena tidak bertentangan dengan Undang-Undang, kesusilaan dan ketertiban umum.

Kesepakatan para pihak harus bebas dari paksaan dan tekanan dari siapapun dan dalam bentuk apapun. Kesepakatan yang diperoleh melalui paksaan mengandung cacat hukum sehingga dalam arti yang sebenarnya perjanjian itu bukanlah suatu kesepakatan. Paksaan dan tekanan yang dialami salah satu pihak menyebabkan orang tersebut dalam keadaan tidak bebas sehingga kondisi itu dapat membebaskannya dari tanggung jawab pelaksanaan prestasi pada pihak lain. Pertanggung jawaban dapat diminta dari seseorang bila orang tersebut dalam keadaan bebas. Jadi kebebasan adalah prasyarat untuk lahirnya pertanggung jawaban. Paksaan dan tekanan dalam perjanjian menyebabkan salah satu pihak tidak dalam keadaan bebas, sehingga pihak yang dirugikan dapat meminta pada Pengadilan Negeri setempat untuk membatalkannya.

Kesepakatan juga berkaitan dengan kedewasaan secara hukum dan kemampuan bertanggung jawab. Seseorang dapat dikatakan dewasa secara hukum jika telah berumur 21 tahun dan atau telah kawin (menikah). Sedangkan kemampuan bertanggung jawab adalah orang yang tidak berada dalam pengampuan, tidak hilang ingatan dan atau tidak sedang dicabut hakhak keperdataannya.

Obyek perjanjian pada dasarnya
meliputi "menyerahkan "melakukan sesuatu" atau "tidak melakukan sesuatu". Ketiga obyek perjanjian tersebut biasa dikenal dengan istilah "prestasi". Perjanjian tanpa prestasi tidak mempunyai arti apa-apa. Obyek perjanjian harus halal berarti memperjanjikan sesuatu yang tidak dilarang oleh undang-undang, kesusilaan dan ketertiban umum. Memperjanjikan sesuatu yang tidak halal dapat berakibat perjanjian itu batal demi hukum (Djumadi, $1955: 15)$.

Selain keempat unsur dan syarat tersebut, setiap perjanjian harus pula dibuat dengan itikad baik, sebab perjanjian tidak hanya mengikat untuk hal-hal yang dengan tegas dinyatakan dalam perjanjian, tetapi juga untuk segala sesuatu yang menurut sifat persetujuan diharuskan oleh kepatutan, kebiasaan dan undang-undang.

Perjanjian yang telah disetujui oleh para pihak berlaku sebagai undang-undang bagi yang menyetujuinya sehingga setiap perubahan terhadap isi perjanjian harus dibuat berdasarkan persetujuan para pihak juga. Perjanjian tidak dapat diubah secara sepihak. Setiap perubahan secara sepihak dapat menyebabkan pihak lain tidak terikat dalam perjanjian. Pihak-pihak yang tidak terikat dalam perjanjian tidak dapat dimintakan pertanggung jawaban jika terjadi sesuatu dengan perjanjian tersebut. Pertanggungjawaban dalam perjanjian merupakan salah satu bagian yang sangat penting. Tanpa adanya pertanggungjawaban maka tidak akan pernah tercapai apa yang menjadi maksud dan tujuan dari perjanjian.

\section{G. Fungsi Perjanjian Kredit}

Perjanjian kredit yang telah ditandatangani para pihak dapat berfungsi sebagai :

Manfaat Analisis Yuridis Dan... 
1. Alat bukti bagi bank dan pemohon kredit guna membuktikan adanya hak dan kewajiban timbal balik antara keduanya.

2. Alat pemantau atau pengawasan kredit yang sudah diberikan, karena perjanjian kredit berisi syarat dan ketentuan dalam pemberian kredit dan pengembalian kredit.

3. Perjanjian pokok yang menjadi dasar dari perjanjian ikutannya, yaitu perjanjian pengikatan jaminan yang bersifat accessor.

4. Alat bukti biasa yang membuktikan adanya hutang pemohon terhadap bank sehingga perjanjian kredit tidak mempunyai kekuatan eksekutorial atau tidak memberikan kekuasaan langsung kepada bank untuk mengeksekusi barang jaminan apabila pemohon kredit tidak mampu melunasi hutangnya (wanprestasi).

\section{H. Bentuk Perjanjian Kredit}

Dasar hukum perjanjian kredit yang mengharuskan secara tertulis mengacu pada pasal 1 ayat 11 UU no.10 tahun 1998 tentang perubahan UU No.7 tahun 1992 mengenai perbankan. Dasar hukum lainnya yang mengharuskan perjanjian kredit berbentuk tertulis adalah instruksi Presidium Kabinet No.15/EK/IN/10/1966 tanggal 10 Oktober 1966, yaitu "Dilarang melakukan pemberian kredit tanpa adanya perjanjian kredit yang jelas antara bank dengan pemohon kredit atau antara Bank Sentral dan bank-bank lainya".

Perjanjian kredit merupakan ikatan atau bukti tertulis antara bank dengan pemohon kredit sehingga harus disusun dan dibuat sedemikian rupa agar setiap orang mudah untuk mengetahui bahwa perjanjian yang dibuat itu adalah perjanjian kredit.

Dalam praktek bank ada 2 bentuk perjanjian kredit yaitu :

1. Perjanjian kredit yang dibuat dibawah tangan artinya perjanjian yang disiapkan dan dibuat sendiri oleh bank

Yustisia Vol.1 No.2 Mei - Agustus 2012 kemudian ditawarkan kepada pemohon kredit untuk disepakati. Untuk mempermudah dan mempercepat kerja bank, biasanya bank sudah menyiapkan formulir perjanjian dalam bentuk standard contract yang isi, syarat-syarat dan ketentuannya disiapkan terlebih dahulu secara lengkap.

2. Perjanjian kredit yang dibuat oleh dan dihadapan Notaris. Yang menyiapkan dan membuat perjanjian ini adalah notaris namun dalam praktek semua syarat dan ketentuan perjanjian kredit disiapkan oleh bank kemudian diberikan kepada notaris untuk dirumuskan dalam akte notariil. Perjanjian ini biasanya untuk pemberian kredit dalam jumlah besar dengan jangka waktu menengah atau panjang, seperti kredit modal kerja dan lain-lain.

\section{Addendum Perjanjian Kredit}

Ketika perjanjian kredit sedang berjalan, adakalanya bank dan pemohon kredit menghendaki perubahan syarat-syarat dan ketentuan dalam perjanjian kredit. Untuk keperluan perubahan tersebut kedua belah pihak memerlukan suatu cara yang disebut amandemen atau addendum.

Addendum adalah perubahan yang dilakukan terhadap suatu perjanjian yang sudah ditandatangani dan berlaku mengikat para pihak yang membuat perjanjian. Untuk melakukan perubahan terhadap perjanjian kredit dalam penerapan atau praktek di perbankan dinamakan addendum, yang maksudnya juga melakukan perubahan terhadap syarat-syarat dan ketentuan terhadap perjanjian yang sudah ditandatangani dan berlaku.

Dalam perjanjian yang sudah ditandatangani biasanya dalam salah satu pasalnya para pihak sepakat untuk membuka kemungkinan terjadinya perubahan obyektif (perubahan isi perjanjian kredit) atau kemungkinan kreditor mengalihkan piutangnya kepada pihak lain (perubahan subyektif). Namun perubahan itu harus dilakukan secara tertulis dan disetujui para pihak.

Manfaat Analisis Yuridis Dan...

158 
Addendum merupakan tehnik atau cara yang mudah untuk melakukan perubahan terhadap perjanjian. Perubahan yang dilakukan adalah pasal-pasal yang disepakati untuk dirubah sedangkan pasalpasal yang tidak dirubah atau masih dipertahankan dianggap masih berlaku. Pada praktek perjanjian kredit, hal ini dapat muncul pada saat pasca pembiayaan, dimana debitor mengalami kesulitan melaksanakan kewajibannya pada kreditor sehingga diperlukan penyesuaian pasal-pasal dalam perjanjian tersebut.

\section{J. Makna Jaminan dan Hukum Jaminan}

\section{Pengertian jaminan}

Mariam Darus Badrulzaman merumuskan jaminan sebagai suatu tanggungan yang diberikan oleh seorang debitur dan atau pihak ketiga kepada kreditur yang menjamin kewajibannya dalam suatu perikatan (Frieda Husni Hasbullah, 2002: 5)

Menurut Thomas Suyatno, ahli perbankan menyatakan bahwa jaminan adalah penyerahan kekayaan atau pernyataan kesanggupan seseorang untuk menanggung pembayaran kembali suatu hutang (Thomas Suyatno, 1989: 70)

J. Satrio berpendapat bahwa hukum jaminan adalah peraturan hukum yang mengatur tentang jaminan-jaminan piutang seorang kreditur terhadap seorang debitur (J. Satrio, 1991: 3)

Hartono Hadisaputro menyatakan jaminan adalah sesuatu yang diberikan debitur kepada kreditur untuk menimbulkan keyakinan bahwa debitur akan memenuhi kewajiban yang dapat dinilai dengan uang yang timbul dari suatu perikatan (Hartono Hadisaputro, 1984: 50).

Didalam memberikan pembiayaan kepada nasabah, selain memperhatikan watak, kemampuan, modal dan prospek usaha penerima pembiayaan, maka bank juga harus memperhatikan tentang jaminan dalam pembiayaan. Jaminan bukan saja

Yustisia Vol.1 No.2 Mei - Agustus 2012 menjadi alat pemenuhan kewajiban jika nasabah tidak mampu atau tidak mau memenuhi kewajibannya, tetapi jaminan juga dapat menjadi tolak ukur kredibilitas dan bonafiditas dari penerima pembiayaan. Semakin baik jaminan yang diberikan, akan semakin baik pula kredibilitas dan bonafiditas dari penerima pembiayaan. Keyakinan bank atas kemampuan dan kesanggupan debitor untuk melunasi pembiayaan sesuai dengan yang diperjanjikan antara lain juga dipengaruhi oleh aspek jaminan ini.

\section{Fungsi jaminan}

Fungsi utama dari jaminan adalah untuk meyakinkan bank atau kreditur, bahwa debitur mempunyai kemampuan untuk mengembalikan atau melunasi kredit yang diberikan kepadanya sesuai dengan persyaratan dan perjanjian kredit yang telah disepakati bersama (Abdul R. Saliman Cs., 2006: 21).

\section{Sifat perjanjian jaminan}

Perjanjian jaminan mempunyai sifat accessoir yaitu perjanjian tambahan yang tergantung pada perjanjian pokoknya. Perjanjian pokok adalah perjanjian pinjam meminjam atau hutang piutang yang diikuti dengan perjanjian tambahan sebagai jaminan. Perjanjian tambahan tersebut dimaksudkan agar keamanan kreditur lebih terjamin dan bentuknya dapat berupa jaminan kebendaan maupun jaminan perorangan (Frieda Husni Hasbullah, 2002: 6-7)

Sifat accessoir dari hak jaminan dapat menimbulkan akibat hukum sebagai berikut :

a. Adanya dan hapusnya perjanjian tambahan tergantung pada perjanjian pokok.

b. Jika perjanjian pokok batal, maka perjanjian tambahan juga batal.

c. Jika perjanjian pokok beralih, maka perjanjian tambahan ikut beralih.

d. Jika perjanjian pokok beralih karena cessie, subrogatie maka Manfaat Analisis Yuridis Dan... 159 
perjanjian tambaan juga beralih tanpa penyeraan khusus.

\section{Macam-macam jaminan}

Ada 2 (dua) jenis jaminan, yaitu jaminan secara umum dan jaminan secara khusus, sedangkan jaminan secara khusus masih terbagi lagi menjadi jaminan kebendaan dan jaminan orang atau penanggungan utang (Oey Hoey Tiong, 1985: 16)

Jaminan yang bersifat umum, yaitu jaminan yang diberikan oleh penerima kepada pemberi pembiayaan, hak-hak tagihan mana tidak mempunyai hak saling mendahului (concurren) antara kreditor yang satu dengan kreditor lainnya. Sedangkan jaminan yang bersifat khusus, adalah jaminan yang diberikan oleh penerima kepada pemberi pembiayaan, hak-hak tagihan mana mempunyai hak mendahului sehingga penerima jaminan mempunyai kedudukan didahulukan dari kreditor lainnya (preferent).

Jaminan Perorangan (personal guarantee) adalah jaminan berupa pernyataan kesanggupan yang diberikan oleh seseorang (pihak ketiga), guna menjamin pemenuhan kewajibankewajiban penerima pembiayaan (debitor) kepada pemberi pembiayaan (kreditor), apabila debitor cidera janji (wanprestasi). Jadi kewajiban penjamin penerima pembiayaan (guaranted) muncul apabila penerima pembiayaan (debitor) ingkar janji/tidak memenuhi apa yang diperjanjikan.

Jaminan umum lahir dan bersumber karena undang-undang, adanya ditentukan dan ditunjuk oleh undang-undang tanpa ada kesepakatan dari para pihak. Jaminan umum timbul dari undang-undang yang bersumber pada pasal 1131 KUHPerdata yang obyeknya adalah semua harta kekayaan atau benda-benda yang dimiliki pemohon kredit seluruhnya baik yang ada sekarang atau yang ada di kemudian hari.

Yustisia Vol.1 No.2 Mei - Agustus 2012
Sedangkan jaminan khusus lahir karena ada kesepakatan antara bank dan pemohon kredit yang dapat berupa jaminan yang bersifat kebendaan atau jaminan bersifat perorangan. Jaminan yang bersifat kebendaan adalah adanya benda-benda tertentu yang disediakan pemohon sebagai jaminan, misalnya tanah, tanah berikut bangunan, mesin-mesin, mobil dan lain-lain. Dan jaminan yang bersifat perorangan adalah pemohon menyediakan orang lain yang menyanggupi untuk melunasi hutang pemohon manakala pemohon kredit cidera janji.

\section{a. Jaminan Kebendaan}

Jaminan kebendaan adalah jaminan yang memberikan kepada kreditor atas suatu kebendaan milik debitor hak untuk memanfaatkan benda tersebut jika debitor melakukan wanprestasi (Frieda Husni Hasbullah, 2002 : 16). Jaminan ini juga bersifat prioriteit artinya siapa yang memegang jaminan atas jaminan kebendaan lebih dahulu maka akan didahulukan pelunasan hutangnya dibandingkan dengan pemegang jaminan hak kebendaan lainnya (F.X. Suhardana, 1992 : 161).

Jaminan kebendaan lahir dan bersumber pada perjanjian. Jaminan kebendaan dapat diadakan antara bank dan pemohon kredit tetapi juga dapat diadakan antara bank dengan pihak pemohon kredit lainnya (pihak ketiga) yang menyediakan harta kekayaannya secara khusus misalnya tanah dan bangunan yang digunakan untuk menjamin dipenuhinya kewajiban pemohon kredit kepada bank.

Jaminan kebendaan bisa berupa benda berwujud bisa pula benda tidak berwujud. Jaminan benda berwujud umumnya berupa benda/barang bergerak dan atau barang tidak bergerak, sedangkan benda tidak berwujud yang lazim diterima bank adalah hak tagih.

Manfaat Analisis Yuridis Dan... 160 
jaminan $^{\text {Jika }} \begin{array}{r}\text { yang } \\ \text { dalam }\end{array}$ perjanjian pembiayaan adalah benda bergerak dan atau tidak bergerak kecuali deposito dan tagihan, maka secara umum yang harus diperhatikan adalah:

1) Jaminan harus secured, artinya jaminan tersebut dapat diadakan pengikatan secara yuridis formal, sehingga apabila kelak dikemudian hari terjadi wanprestasi maka pemberi pembiayaan telah mempunyai alat bukti yang sempurna dan lengkap untuk menjalankan suatu tindakan hukum.

2) Jaminan harus marketable, artinya jika jaminan tersebut harus, perlu dan dieksekusi, maka jaminan tersebut dapat dengan mudah dijual atau diuangkan untuk melunasi pembiayaan.

Selain memperhatikan ketentuan umum tersebut, maka jika yang dijadikan jaminan adalah tanah, tanah dan bangunan, kapal dan mesin-mesin pabrik yang melekat dengan tanah, maka hal-hal yang harus diperhatikan oleh pemberi pembiayaan adalah : Legalitas dan status tanah (hak-hak yang melekat pada tanah), letak dan luasnya, harga pasaran setempat dan harga jual menurut perpajakan, pajak-pajak, keadaan dan kondisinya.

Sebagaimana telah dikemukakan pada bagian awal, bahwa salah satu fungsi jaminan sebagai sarana pelunasan pembiayaan nasabah, maka mengamankan jaminan merupakan sesuatu yang penting. Langkahlangkah pengamanan tersebut pada dasarnya ingin menghindari dari "sudah jatuh ketimpa tangga". Maka jaminan dalam pembiayaan harus dilakukan pengikatan atau pembebanan hak. Jenis-jenis pengikatan hak tersebut antara lain

a) Hak tanggungan

Menurut Undang-undang Nomor 5 Tahun 1960 (UUPA), hak jaminan yang dibebankan pada tanah, berikut atau tidak berikut benda-benda lain yang merupakan satu kesatuan dengan tanah itu, untuk pelunasan hutang tertentu, yang memberikan kedudukan yang diutamakan kepada kreditor tertentu terhadap kreditor-kreditor lainnya.

Hal-hal penting yang harus diperhatikan dalam hak tanggungan adalah obyek tanggungan (umumnya tanah/benda tidak bergerak) serta proses hukum terbitnya hak tanggungan, apakah melalui proses pemberian surat kuasa memasang hak tanggungan atau tidak dan pemasangan akta hak tanggungannya dibuat dimana.

b) Gadai

Gadai ialah suatu hak yang diperoleh seorang kreditor atas suatu barang bergerak, yang diberikan kepadanya oleh debitor untuk menjamin suatu hutang dan yang memberikan kewenangan kepada kreditor untuk mendapatkan pelunasan dari barang tersebut lebih dahulu dari kreditor-kreditor lainnya, dengan terkecuali biaya-biaya untuk melelang barang tersebut dan biaya yang telah dikeluarkan untuk memelihara benda itu, biayabiaya mana harus didahulukan (Sri Soedewi, 1975 : 97).

c) Fidusia

Adalah pengalihan hak kepemilikan suatu benda atas dasar kepercayaan dengan ketentuan bahwa benda yang hak kepemilikannya dialihkan

Manfaat Analisis Yuridis Dan...

161 
tetap dalam penguasaan pemilik benda. Jaminan Fidusia adalah Hak Jaminan atas benda bergerak baik yang berwujud maupun yang tidak berwujud dan benda tidak bergerak khususnya bangunan yang tidak dapat dibebani hak tanggungan sebagaimana dimaksud dalam UU No. 4 Tahun 1996 tentang Hak Tanggungan yang tetap berada dalam penguasaan Pemberi Fidusia, sebagai agunan bagi pelunasan hutang tertentu yang memberikan kedudukan yang diutamakan kepada Penerima Fidusia terhadap kreditor lainnya.

d) Cessie

Adalah pengalihan tagihan hutang, yaitu penyerahan akad piutang atas nama dan kebendaan tak bertubuh lainnya yang dilakukan dengan cara membuat suatu akta otentik atau dibawah tangan, dengan mana hak-hak atas kebendaan itu telah dilimpahkan kepada orang lain.

\section{b. Jaminan Perorangan}

Jaminan penanggungan hutang telah terjadi apabila pihak ketiga mengikatkan diri memenuhi perikatan debitor utama sebagai peminjam yang tidak memenuhi kewajibannya guna kepentingan kreditor (Indrawati Soewarso, 2002 : 18).

Karena perjanjian tersebut adalah perorangan dan atau badan hukum, maka ada beberapa hal yang harus diperhatikan oleh seorang account manager :

1) Penjamin dari perorangan harus dibuat dalam perjanjian tersendiri secara terpisah dari perjanjian pokok tapi tetap merupakan satu kesatuan

Yustisia Vol.1 No.2 Mei - Agustus 2012 dengan perjanjian pokok, sebab perjanjian jaminan merupakan perjanjian acesoir (tambahan). Jika perjanjian pokok cacat maka perjanjian tambahan juga menjadi cacat.

2) Jika penjamin telah berkeluarga, maka harus ada persetujuan dari keluarganya, baik suami maupun istri, sebab dikhawatirkan harta yang dijaminkan adalah harta gonogini, atau jika si penjamin meninggal dunia maka ahli warisnya wajib melanjutkan kewajiban si pewaris.

3) Jika penjamin adalah badan hukum (perusahaan) harus dipelajari anggaran dasar dan anggaran rumah tangganya untuk mengetahui secara tepat apakah badan hukum itu melalui pengurusnya diperbolehkan menjadi penjamin, lalu siapa dari pengurus yang diperbolehkan bertindak mewakili badan hukum tersebut untuk menjadi penjamin.

4) Dalam perjanjian penjaminan harus dimasukkan kláusula yang menyebutkan bahwa penjamin/penanggung melepaskan hak istimewanya yang diatur dalam KUHPerdata. Misal tentang penagihan secara langsung kepada penjamin tanpa menunggu penjualan asset milik penerima pembiayaan.

5) Penjamin harus diberitahu atau harus mengetahui adanya setiap perubahan dari perjanjian tersebut, baik perubahan jangka waktu perjanjian, jumlah yang diperjanjikan maupun obyek yang diperjanjikan dan lain sebagainya. Pada pokoknya jika perjanjian pokok berubah maka perjanjian tambahan harus disesuaikan dengan perubahan perjanjian pokok.

Manfaat Analisis Yuridis Dan... 162 


\section{K. Kredit Macet Sebagai Resiko Bank Yang Harus Dihindari}

\section{Pengertian Kredit Macet}

Kredit macet selalu ada dalam kegiatan Perkreditan bank karena tidak mungkin menghindari $100 \%$ dari kemungkinan munculnya kredit macet. Bank hanya berusaha menekan seminimal mungkin besarnya kredit bermasalah agar tidak melebihi ketentuan Bank Indonesia sebagai pengawas perbankan. Bank Indonesia melalui Surat Keputusan Direksi Bank Indonesia nomor 31/147/KEP/DIR tanggal 12 November 1998 memberikan penggolongan mengenai kualitas kredit, sebagai berikut : Kredit Lancar (KL), Kredit dalam Perhatian Khusus (KPK), Kredit Kurang Lancar (KKL), Kredit Diragukan (KD) dan Kredit Macet (KM).

KL adalah kredit yang pembayarannya tepat waktu dan tidak ada tunggakan. KPK adalah kredit dengan tunggakan pembayaran pokok dan atau bunga selama 30 hari. KKL adalah kredit dengan tunggakan pembayaran pokok dan atau bunga dengan waktu antara 90 hari s/d 180 hari. KD adalah kredit dengan tunggakan pembayaran pokok dan atau bunga antara $180 \mathrm{~s} / \mathrm{d} 270$ hari. KM adalah kredit dengan tunggakan pokok dan atau bunga diatas 270 hari.

2. Pendekatan Sosiologis dan Yuridis Sebagai Landasan Strategi Mengatasi Kredit Macet

Kredit macet adalah beban bagi bank karena ia dapat menyebabkan bank kehilangan keuntungan (memasukan dana), padahal sebagian dari pemasukan tersebut harus dikeluarkan untuk membayar hak penabung dan biaya operasional bank (gaji pegawai dan lainlain). Bila angka kredit macet semakin tinggi dapat membahayakan kelangsungan hidup bank tersebut. Itulah sebabnya kredit macet ini menjadi salah satu indikator penentu kinerja sebuah bank.

Yustisia Vol.1 No.2 Mei - Agustus 2012
Kondisi ini menuntut untuk melakukan penilaian ulang secara periodik terhadap actual loan problem dan potential loan problem agar sedini mungkin bank dapat mengambil langkah-langkah pengamanan yang akurat, baik menggunakan pendekatan sosiologis dalam bentuk persuasif (berorientasi pada penyelamatan kredit) maupun pendekatan yuridis dalam bentuk legal-coercion (berorientasi pada penyelesaian kredit).

Tahap penyelamatan kredit belum memanfaatkan lembaga hukum karena pemohon masih kooperatif dan prospek usaha masih feasible, sehingga langkah semacam ini disebut restrukturisasi. Adapun bentuk-bentuk penyelamatan kredit bermasalah melalui rekstrukturisasi menurut Surat Direktur BI Nomor: 31/150/KEP/DIR, Tanggal 12 Nopember 1998 adalah: Penurunan suku bunga kredit, pengurangan tunggakan bunga kredit, pengurangan tunggakan pokok kredit, perpanjangan jangka waktu kredit, penambahan fasilitas kredit, pengambil alihan agunan/asset pemohon kredit, jaminan kredit dibeli oleh bank, novasi (pembaharuan hutang), subrogasi, penghapusan piutang.

langkah tersebut adalah:

Penjelasan dari langkah-

a. Penurunan suku bunga tidak merubah perjanjian ikutannya (perjanjian jaminan) karena hanya merubah ketentuan dan syarat dalam perjanjian pokok.

b. Pengurangan tunggakan bunga kredit tidak mengakibatkan perubahan akte perjanjian kredit karena yang dikurangi adalah besarnya tunggakan bunga yang seharusnya dibayar debitor.

c. Pengurangan tunggakan pokok bertujuan untuk memperingan debitor dengan cara penghapusan bunga dan denda seluruhnya.

d. Perpanjangan jangka waktu kredit bertujuan memperingan debitor untuk mengembalikan hutangnya.

Manfaat Analisis Yuridis Dan... 
e. Penambahan fasilitas kredit harus dibuatkan akta perjanjian kredit baru atau dilakukan addendum terhadap perjanjian kredit lama.

f. Pengambil alihan agunan pemohon kredit adalah untuk menyelamatkan debitor agar hutang debitor dinyatakan lunas.

g. Untuk menyelamatkan kredit, bank dapat membeli agunan melalui penjualan umum atau lelang, karena undang-undang melarang bank memiliki langsung agunan tersebut.

h. Novasi adalah suatu perjanjian baru yang menghapuskan perjanjian lama dan pada saat yang sama memunculkan perjanjian baru yang menggantikan perjanjian lama, agar debitor dapat segera melunasi hutangnya.

i. Subrogasi adalah penggantian hak bank oleh pihak ketiga yang telah membayar hutang debitor kepada bank.

j. Penghapusan piutang adalah pembebasan hutang debitor oleh bank, baik seluruh atau sebagian dikarenakan hutangnya, telah kadaluarsa menurut hukum.

Semua langkah-langkah

tersebut dapat dikelompokkan dalam istilah-istilah: Rescheduling, reconditioning dan restructuring (Misahardi Wilamarta, 2006: 46).

Langkah-langkah
penyelamatan kredit tersebut
menggunakan pendekatan sosiologis
yang pada hakikatnya bertujuan untuk
menciptakan kebersamaan dalam
menyelesaikan pembiayaan bermasalah
dengan harapan debitor memahami
situasi dan kondisi yang ada pada bank
dan kemungkinan-kemungkinan yang
akan terjadi apabila debitor tetap tidak
memenuhi kewajibannya. Langkah
persuasif ini memerlukan keahlian dan
seni bernegosiasi, karena harus tampil
sebagai sosok yang bersimpati dan
berempati terhadap debitor. Jika debitor
masih memiliki itikad baik untuk
melunasi hutangnya maka pendekatan
ini efektif dan efisien.

Yustisia Vol.1 No.2 Mei - Agustus 2012
Apabila pendekatan sosiologis diatas tidak membuahkan hasil maka bank dapat melakukan strategi penyelesaian kredit melalui bentuk pendekatan yuridis lewat upaya paksa melalui pengadilan (legal-coercion) dengan cara memberi Surat Peringatan (SP) I, II dan III.

Surat Peringatan I belum bersifat ancaman secara hukum, tetapi lebih pada pengungkapan fakta-fakta dan harapan-harapan agar debitor melaksanakan kewajibannya. Ingatkan debitor pada peristiwa dimana ia sangat memerlukan 'uluran tangan' dari kreditor. Jika ini belum berhasil, segera layangkan Surat Peringatan II yang berisi sedikit penekanan dan kemukakan dalam surat tersebut bahwa Account Manager atau Account Officer akan berusaha untuk meyakinkan pihak bank agar tidak perlu segera mengambil langkah-langkah hukum. Bila cara ini juga tidak membuahkan hasil, kirimkan Surat Peringatan III, yang isinya menyatakan bahwa pihak bank meminta agar masalah tersebut diselesaikan secara hukum.

\begin{tabular}{lcrr}
\multicolumn{1}{c}{ Jika } & \multicolumn{2}{c}{ ancaman } & untuk \\
menggunakan & upaya & hukum tidak \\
membuat & debitor & memenuhi \\
kewajibannya, & maka & segera ajukan
\end{tabular} permohonan kepada Pengadilan Negeri agar pengadilan memberi somasi pada debitor untuk segera memenuhi kewajibannya. Bila somasi tersebut tidak juga diperhatikan dan dipenuhi maka segera ajukan permohonan sita eksekusi terhadap jaminan pembiayaan kepada pengadilan. Atas dasar permohonan tersebut, pengadilan akan melakukan langkah-langkah: Aanmaning, penyitaan dan pelelangan terhadap obyek jaminan. Apabila obyek jaminan yang telah dilakukan penjualan melalui lelang berada dalam keadaan kosong, maka obyek lelang tersebut langsung diserahkan kepada pemenang atau pembeli lelang, tetapi jika obyek tersebut dalam keadaan tidak kosong, maka perlu diajukan permohonan pengosongan obyek lelang kepada pengadilan dan selanjutnya pengadilan

Manfaat Analisis Yuridis Dan...

164 
akan melakukan upaya pengosongan secara paksa, jika pengosongan secara sukarela tidak dapat dilaksanakan.

Strategi penyelamatan kredit berdasarkan pendekatan sosiologis (non litigasi) berorientasi pada win-win solution melalui bottom-up process, sedangkan strategi penyelesaian kredit dengan pendekatan yuridis berupa legal-coercion (litigasi) berorientasi pada win-lose solution melalui topdown process.

Pendekatan yang bersifat bottom-up process menempatkan kedua belah pihak pada posisi sejajar yang masing-masing tetap memiliki otonomi sehingga masih memiliki kebebasan untuk menentukan isi kesepakatan para pihak.

Sedangkan pendekatan yuridis yang bersifat top-down process, menempatkan kedua belah pihak telah kehilangan otonomi karena bentuk penyelesaian ditentukan bukan oleh para pihak melainkan oleh peraturan perundang-undangan yang berlaku. Dengan kata lain, undang-undanglah yang menentukan bentuk penyelesaiannya, bukan bagi keinginan para pihak.

\section{Penutup}

Berdasarkan uraian diatas dapat disimpulkan bahwa bisnis jasa perbankan khususnya pemberian kredit, dibangun diatas kepercayaan antara bank dengan debitor adalah sesuatu yang rentan karena tidak ada seorang pun atau satu cara pun yang dengan pasti dapat mencegah debitor melakukan wanprestasi. Debitor yang tidak mau memenuhi kewajibannya dapat disebabkan karena dari semula memang ada itikad tidak baik (sejak semula sulit diprediksi) dan atau karena melakukan kesalahan manajemen dalam pengelolaan dana pinjaman.

Yang menjadi masalah bagi bank meski debitor tidak dapat melaksanakan kewajibannya, bank tetap harus melaksanakan kewajibannya terhadap kreditor (penabung) yang tidak mau tahu adanya kredit macet tersebut. Itu sebabnya bank terpaksa melakukan 2 (dua) macam strategi, yaitu: penyelamatan kredit (menggunakan analisis sosiologis) dan penyelesaian kredit (menggunakan analisis yuridis).

Bila analisis sosiologis terhadap unsur character, capital, capacity dan condition of economic pada saat proposal diajukan akurat (menguntungkan) dan analisis yuridis terhadap collateral (perjanjian tambahan) serta perjanjian kredit (perjanjian pokok) adalah sah secara hukum, maka bank pada posisi yang menguntungkan dan aman sehingga akan lebih mudah menerapkan strategi penyelamatan dan atau strategi penyelesaian kredit terhadap kredit macet yang muncul. Strategi apapun yang dipilih, posisi bank relatif aman karena langkahlangkah tersebut memiliki landasan hukum yang kuat. Berbeda jika perjanjian pokoknya (perjanjian kredit) dan perjanjian tambahan (perjanjian jaminan) adalah batal demi hukum dan atau dapat dibatalkan, maka posisi bank menjadi lemah karena strategi apapun yang akan dilakukan oleh bank akan menjadi tidak sah. Disinilah terlihat arti pentingnya complementary approach antara analisis yuridis dengan analisis sosiologis untuk meminimalisir resiko bank sebagai kreditor. 


\section{DAFTAR PUSTAKA}

\section{Buku}

Abdulkadir Muhammad, Pengantar Hukum Perusahaan Indonesia, PT. Citra Aditya Bakti, Bandung, 1995.

Abdul R. Salman Cs., Hukum Bisnis Untuk Perusahaan, Teori \& Contoh Kasus, Kencana Prenada Media Group, Jakarta, 2006.

Adrian Sutedi, Hukum Perbankan Suatu Tinjauan Pencucian Uang, Merger, Likuidasi, dan Kepailitan, Sinar Grafika, Jakarta, 2007.

Djumadi, Hukum Perburuhan Perjanjian Kerja, Edisi Revisi, PT. Raja Grafindo Perkasa, Jakarta, 1995.

Frieda Husni Hasbullah, Hukum Kebendaan Perdata Hak-hak Yang Memberi Jaminan, Jilid 2, Ind-Hill Co, Jakarta, 2002.

F.X. Suhardana, Hukum Perdata I, Gramedia, Jakarta, 1992.

Hartono Hadisaputro, Pokok-pokok Hukum Perikatan dan Hukum Jaminan, Liberty, Yogyakarta, 1984.

Harry Hamersma, Tokoh-tokoh Filsafat Modern, Gramedia, Jakarta, 1984.

Indrawati Suwarso, Aspek Hukum Kredit Jaminan, Institut Bisnis Indonesia, Jakarta, 2002.

J. Satrio, Hukum Jaminan. Hak-hak Jaminan Kebendaan, PT. Citra Aditya, Bandung, 1991.

Marhainis Abdulhay, Hukum Perdata Material Jilid II, Pradya Paramita, Jakarta, 1983.

Mariam Darus, Aneka Hukum Bisnis, Alumni, Bandung, 2001.

, Permasalahan Hukum Hak Jaminan, Hukum Bisnis, Volume 11, 2000.

Misahardi Wilamarta, Eksistensi Kredit Sindikasi Dalam Perjanjian Kredit Sindikasi Dalam Perjanjian Kredit Perbankan, Center for Education and Legal Studies (CELS), Depok, 2006.

, Penerapan Prinsip-prinsip Good Corporate Governance Dalam Perseroan Terbatas, Center for Education and Legal Studies (CELS), Depok, 2007.

Oey Hoey Tiong, Fiducia Sebagai Jaminan Unsur-unsur Perikatan, Ghalia Indonesia, Jakarta, 1985.

R. Subekti, Hukum Perjanjian, PT. Pembimbing Masa, Jakarta, 1963.

Sri Soedewi Masjchoen Sofwan, Hukum Perdata : Hukum Benda, Liberty, Yogyakarta, 1975.

Thomas Suyatno, Dasar-dasar Perkreditan, Gramedia, Jakarta, 1989.

Zulfadli Barus, Causa Dalam Perjanjian, Jurnal Yuridis, Vol. 1 No. 2, (ISSN: 1693 4458), FH-UPN "Veteran" Jakarta, Jakarta, 2004. , Berfikir Kritis \& Sistemik Dalam Filsafat Hukum, FH UPN "Veteran” Jakarta, 2004. , Akar Konseptual Legal Reasoning Dalam Filsafat Hukum, CELS, Depok, 2009. 


\section{Peraturan Perundang-undangan}

Kitab Undang-undang Hukum Perdata.

Indonesia, Undang-undang Nomor 5 Tahun 1960, tentang Ketentuan Pokok Agraria.

, Undang-undang Nomor 10 Tahun 1998, tentang Perbankan.

, Undang-undang Nomor 4 Tahun 1996, tentang Hak Tanggungan Atas Tanah Beserta Bendabenda Yang Berkaitan Dengan Tanah.

, Undang-undang Nomor 42 Tahun 1999, tentang Jaminan Fidusia.

, Instruksi Presidium Kabinet Nomor 15/BK/IM/10/1966.

, Keputusan Direksi Bank Indonesia Nomor 31/147/KEP/DIR/1998.

, Surat Direktur Bank Indonesia Nomor 31/150/KEP/DIR/1998. 


\section{BIODATA PENULIS}

\section{PENULIS PERTAMA}

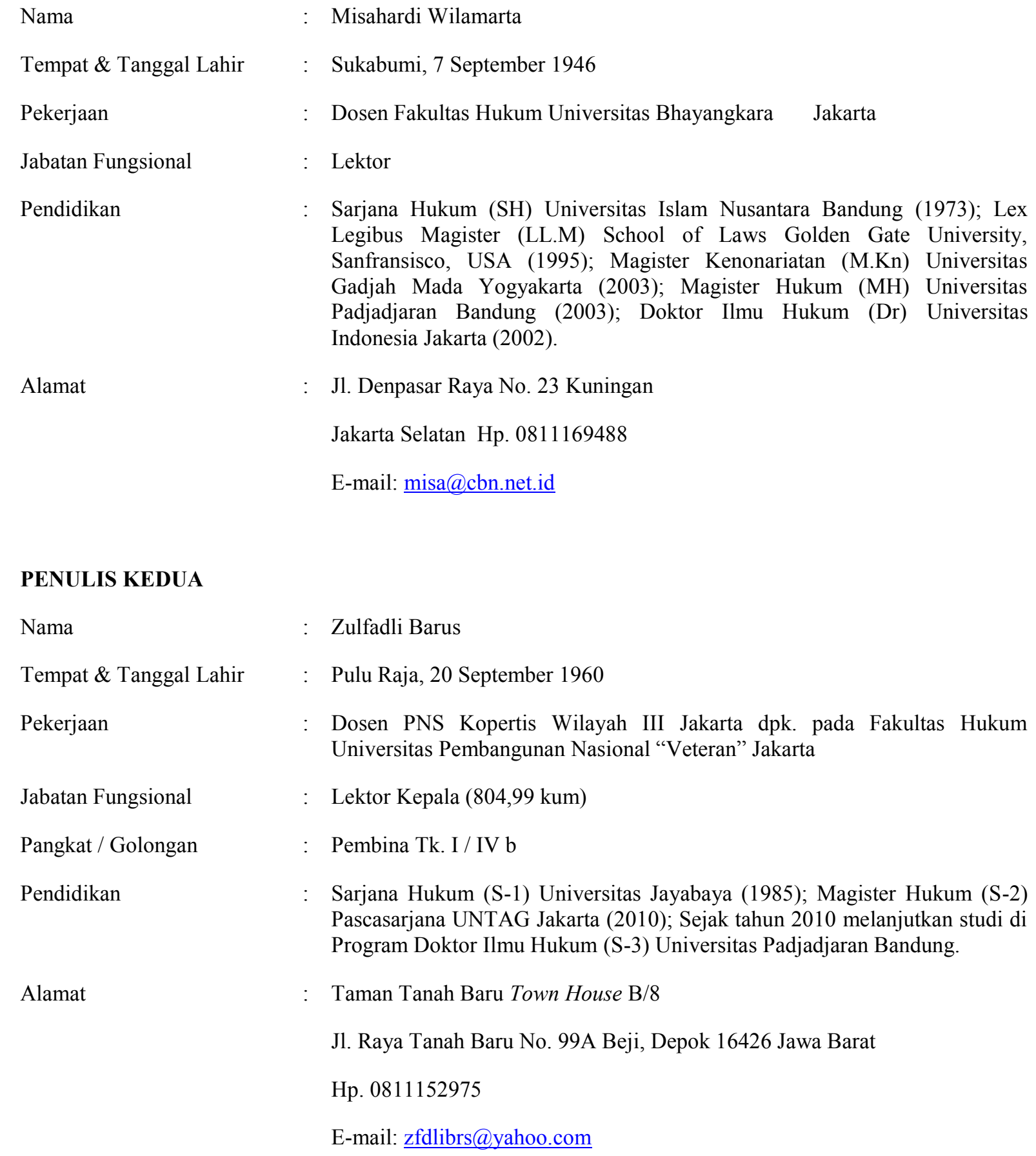

\section{PENULIS KEDUA}

